\title{
KNEE OSTEOCHONDRITIS DESICCANS: SURGERY ALGORITHM
}

\author{
Egiazaryan KA, Lazishvili GD凶, Hramenkova IV, Shpak MA, Badriev DA
}

Department of Traumatology, Orthopedics and Military Field Surgery,

Pirogov Russian National Research Medical University, Moscow

\begin{abstract}
Knee osteochondritis desiccans, or Koenig's disease, is commonly found in active young people engaged in manual labor, sports etc., i.e. socially active population. Today, we have a good number of surgical method to treatment of this disorder; however, there is still much controversy about their application, and no single approach is considered to be the optimal one. Plus, high-quality biomaterials required for the intervention are sometimes unavailable. The analysis of the results of treatment of patients (spanning several years) proved urgency of the problem and highlighted the necessity to solve a number of related issues. This paper presents the algorithm of surgical treatment of knee osteochondritis desiccans. We have provided surgery validation criteria, suggested optimal methods of correction of local cartilage defects (depending on the degree of damage and patient's age) and outlined some recommendations based on our practical experience.
\end{abstract}

Keywords: local cartilage defects, knee joint, osteochondritis dissecans, Koenig's disease, osteochondral defect, collagen scaffold, mosaic plastic

$\triangle$ Correspondence should be addressed: Guram Davidovich Lazishvili Ostrovityanova 1, Moscow, 117997; guramlaz@gmail.com

Received: 16.05.18 Accepted: 23.05.18

DOI: $10.24075 / \mathrm{brsmu} .2018 .020$

\section{АЛГОРИТМ ХИРУРГИЧЕСКОГО ЛЕЧЕНИЯ БОЛЬНЫХ С РАССЕКАЮЩИМ ОСТЕОХОНДРИТОМ КОЛЕННОГО СУСТАВА}

\author{
К. А. Егиазарян, Г. Д. Лазишвили凶, И. В. Храменкова, М. А. Шпак, Д. А. Бадриев \\ Кафедра травматологии, ортопедии и военно-полевой хирургии, \\ Российкий национальный исследовательский медицинский университет имени Н. И. Пирогова
}

\begin{abstract}
Наиболее часто рассекающий остеохондрит коленного сустава, или болезнь Кёнига, встречается у активных молодых людей, занятых физическим трудом, спортом, т. е. представителей социально активной прослойки населения. Несмотря на разнообразие современных методик хирургического лечения болезни, остается много спорных вопросов по их применению, отсутствует оптимальный подход и ограничена доступность качественных биоматериалов, требующихся при вмешательстве. Проведенный анализ результатов лечения пациентов за несколько лет показал высокую актуальность и необходимость решения многих вопросов этой проблемы. В работе представлен алгоритм хирургического лечения рассекающего остеохондрита коленного сустава. Обоснованы показания к оперативному вмешательству, предложены оптимальные способы коррекции локальных дефектов хряща в зависимости от стадии его поражения и возраста пациента, даны рекомендации, основанные на практическом опыте авторов.
\end{abstract}

Ключевые слова: локальные дефекты хряща, коленный сустав, рассекающий остеохондрит, болезнь Кёнига, костно-хрящевой десект, коллагеновая матрица, «мозаичная» костно-хрящевая аутотрансплантация

Для корреспонденции: Гурам Давидович Лазишвили

ул. Островитянова, д. 1, г. Москва, 117997; guramlaz@gmail.com

Статья получена: 16.05.18 Статья принята к печати: 23.05.18

DOI: $10.24075 /$ vrgmu.2018.020

Treatment of the hyaline cartilage pathology is a problem regarded by current orthopedics as urgent. Surgery aimed at local cartilage defects correction is one of the most difficult tasks a surgeon can have today.

Osteochondritis desiccans (Koenig's disease) in femoral condyle makes up $2 \%$ of all knee joint disorders. The pathology mainly affects people 11 to 13 and 20 to 40 years old.

Every year, surgeons in Europe perform over 300,000 operations aimed at correction of local intraarticular cartilage defects of the knee joint [1]. Many of the previously popular surgery methods applied to remedy the disorder, like cartilaginous plate anchoring, subchondral bone tunneling etc, have proved ineffective and are quite outdated.

In $80-85 \%$ of cases, osteochondritis desiccans manifests around the medial femoral condyle; in $10-20 \%$ of cases around lateral femoral condyle; in 4\% — on the articular surface of patella and in $0.5-0.7 \%$ of cases - around the femoral intercondylar groove. In 14-24\% of cases, Koenig's disease is bilateral [2].
The reasons behind damage to cartilage accompanying osteochondritis desiccans are not quite clear. The list of these reasons may include constitutional and genetic factors, ischemia, traumas, bone overload disorders, ossification disorders etc [3]. Probably, Koenig's disease is the result of ischemia and local necrosis of the subchondral bone that spreads onto cartilage. Development of osteochondritis desiccans leads to separation of the subchondral bone's necrotic fragment and its transfer to the joint's cavity.

There are many diverse surgery approaches to the Koenig's disease, and some of them imply making use of advanced biotechnology; however, numerous related questions remain unanswered [4-8]. Simultaneous osteochondral reconstruction (and the necessity thereof) is one of the subjects of discussion. Lack of a common opinion and related standards complicates validation of methods chosen to treat a case of Koenig's disease, especially in juvenile patients with open physes.

Unfortunately, the choice our surgeons have today when treating osteochondritis desiccans is very limited. The reason 
behind such a state of affairs is unavailability of a wide range of techniques and tools offered by current biological and cellular technologies. National R\&D centers have not yet offered viable alternatives to the imported biomaterials, the cost of which makes them inexpedient in the context of routine treatments in Russian hospitals.

Analysis of the long-term outcomes of bone-cartilage autotransplantation ("mosaic" chondroplasty, commonly used by Russian practitioners) has revealed the drawbacks of this approach: 1) frequently observed non-restoration of the joint surfaces' congruence, as well as that of the defect itself; 2) problematic consequences seen around the patello-femoral articulation. One of the main causes of complications arising during surgery on extensive osteochondral defects of femoral condyles is the deficit of osteoplastic material.

This paper presents the optimal algorithm of surgical treatment of femoral condyle osteochondritis desiccans (depending on the cartilage damage severity) and validation thereof.

\section{Study Design}

To develop the optimal treatment algorithm addressing the disorder in question, as well as validation points thereof, we have analyzed the results observed in 184 patients with various chronic knee injuries (full-thickness local cartilage and osteochondral) treated from 1995 to 2017 in Hospital \#1 named after N.I. Pirogov.

The patients were divided into two groups, treatment (1st) and control (2nd). The first group included 86 patients; they were treated following current local cartilage defects surgical correction protocols (mono or "mosaic" bone/cartilage auto- or allotransplantation, autologous matrix-induced chondrogenesis - AMIC - implantation of collagen matrix with or without bone grafting) [12].

The second group consisted of 98 patients; their treatment followed older local cartilage defects correction practices (abrasive chondroplasty, subchondral bone micro-fractures, tunneling) [2-5, 6].

Duration of the condition was estimated from case records, i.e. from the day a patient first noticed the disorder to the day that patient was diagnosed with Koenig's disease.

Examination and treatment results assessment methods employed: clinical and functional checkup, MRI and multispiral computed tomography (MSCT); scales used to assess condition in pre- and postoperative periods: ICRS physical activity scale (ICRS - International Cartilage Repair Society), VAS (visual analogue scale), WOMAC knee score [2].

Hounsfield scale was used to analyze and assess treatment results as shown by the CT scans of the patients' knee joints. MOCART scale was employed to assess the MRI scans [9-11].

Inclusion criteria: male and female patients aged 15 to 60 years (mean age $40 \pm 1.6$ years); chronic full-thickness knee cartilage defects, 3rd and 4th stage (ICRS classification).

Exclusion criteria: age under 15 or over 60 ; 1 st or 2 nd stage of the knee cartilage defects (not full-thickness, fresh injury).

We have analyzed the long-term (up to 8 years) treatment results observed in 70 patients $(81.4 \%)$ of the treatment group and 78 patients $(79.6 \%)$ of the control group. This is not the entire sample; the reasons behind the discrepancy are unavailability of a number of patients and recency of surgery in some cases.

Below, we outline the knee osteochondritis desiccans surgery algorithm we have developed and employ in our hospital; it is based on the aforementioned research effort.

\section{Knee Osteochondritis Desiccans: Surgical Correction}

\section{Patients with open physes}

Today, Russian hospitals have a number of options when it comes to surgical correction of local osteochondral defects of femoral condyles, intercondyle groove, kneecap.

We believe that osteochondral transplantation is an inappropriate choice for juvenile patients with open physes. Anchoring the detached necrotic osteochondral plate is also a prospectless option. AMIC, collagen matrix implantation onto necrotic subchondral bone, will not result in regeneration of the latter. We have verified that subchondral bone continues to decay when AMIC does not imply using a bone plate. See more on this technology below.

Thus, the method of choice for patients of this age group is tunneling, i.e. drilling holes in the subchondral bone to stimulate repairs done by mesenchymal stem cells that enter through those holes [12]. Lately, we have been doing that arthroscopically, using a $3.5 \mathrm{~mm}$ triangular bit drill with a stopper limiting depth to $15 \mathrm{~mm}$ (Fig. 1).

\section{Patients with closed physes}

\section{"Mosaic" osteochondral autotransplantation}

If the patient's physes are closed and the osteochondral defect measures less then $10 \mathrm{~cm}^{2}$, we recommend "mosaic" bone and cartilage autotransplantation.

Planning the operation, it is important to determine if the full-scale osteochondral autotransplantation can be done arthroscopically, since it is not always possible practice this approach to collect donor transplant columns, do "mosaic" osteoplasty and articular surface congruence restoration [13, 14]. As a rule, the arthroscopic access itself imposes such limitations through restricting the use of instruments. Such cases call for "mosaic" chondroplasty (open or minimally invasive variations) [15].

There is an important aspect of surgery to consider, namely location of the transplants. Full-scale chondrogenesis and affected cartilage regeneration require transplants placed as close to each other as possible, almost sticking together or even slightly overlapping.

CT scans made 12 months after surgery prove that osteochondral regeneration in the "mosaic" zone went well (Fig. 2).

Up to early 2017, we resorted to "mosaic" osteochondral allotransplantation when the defect's area was greater than $10 \mathrm{~cm}^{2}$. We used lyophilized canned femoral condyles as donor allomaterial, which was sterilized with gamma rays. The surgery's technique and the arrangement of transplants were same to osteochondral autotransplantation (Fig. 3).

We believe that this method offers a number of advantages. First off, there is no need to collect autologous donor transplant posts from the sides of the knee joint, which makes the surgery shorter and less traumatic. Secondly, if the defect's area is small, the operation can be done arthroscopically. Thirdly, there is always a good supply of grafting materials, which allows using allotransplants of different diameters for full-scale osteochondral osteoplasty. Fourthly, there is no need to use biomaterials, which makes the surgery considerably less costly. Fifthly, localization of the osteochondral defect does not matter, the method is a viable solution for knee and other joints.

Today, we often resort to the combined (auto- and allo-) "mosaic" osteochondral transplantation (Fig. 4). Typically, 

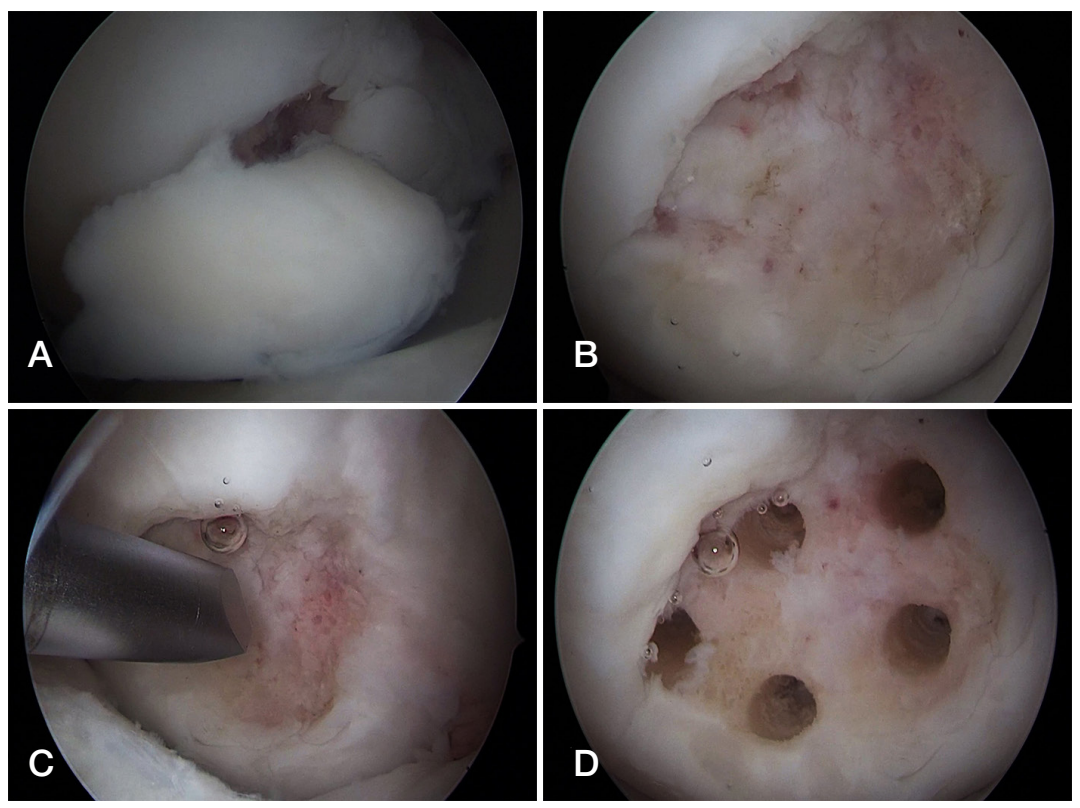

Fig. 1. A. Separated necrotic cartilage plate, arthroscopic view. B. Osteochondral defect after removal of the necrotic plate, arthroscopic view. C. Drilling holes (tunnels) in the subchondral bone. D. Subchondral bone after tunneling
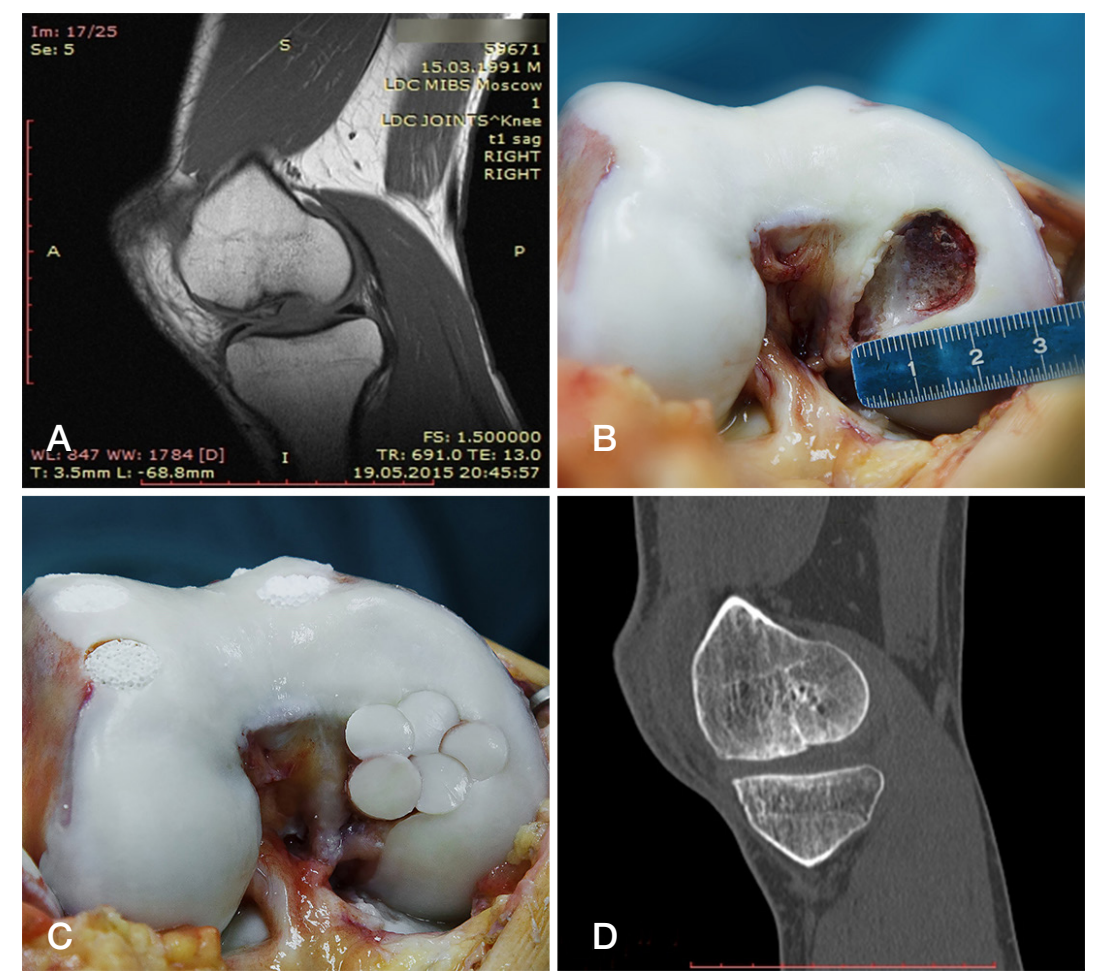

Fig. 2. A. Osteochondritis desiccans affecting medial femoral condyle, MRI scan. B. Condyle defect shape and size after sanation. C. Result of "mosaic" osteochondral autotransplantation. Donor sites filled with biocomposite bone. D. 12 months after operation, MSCT scan. Osteochondral regeneration in the "mosaic" zone went well

it ensures better regeneration of the subchondral bone and cartilaginous surface of the femoral condyle.

Here is the list of our recommendations pertaining to the osteochondral transplantation technique:

- full-scale osteoplasty of a osteochondral defect requires transplants with the diameter of 5-6 mm or greater;

- complete regeneration requires transplants placed as close to each other as possible, sticking together or even slightly overlapping;

- if the defect's area exceeds $10 \mathrm{~cm}^{2}$, adequate (presurgery) assessment of very possibility of complete elimination of that defect is crucial for success; combined auto- and alloplastic approach is a viable solution when there is a risk of shortage of autoplastic material.

\section{Subchondral bone microfracturing (Steadman technique)}

From 2002 to 2005, when faced with a 3rd stage local femoral condyles cartilage defect (contacts, $5 \mathrm{~cm}^{2}$ maximum), we often resorted to subchondral bone microfracturing, or the Steadman technique $[2,4,5]$. This method implies stimulation of chondrogenesis by stem cells obtained through the openings formed. Analysis of the outcomes of such operations showed that they are prospectless: the Steadman's technique does not 
deliver the results expected, i.e. cartilage does not regenerate in the affected area. These outcomes are a yet another prove of this fact: normal chondrogenesis requires anchoring stem cells in the cartilage defect area as a super-clot.

\section{Autologous matrix-induced chondrogenesis (AMIC)}

Lately, practitioners have been choosing the autologous matrix-induced chondrogenesis technique (AMIC) more often when faced with full-thickness cartilage defects (Fig. 5).
AMIC makes use of the above-described reparative ability of mesenchymal stem cells that enter the joint cavity through holes drilled in the subchondral bone [17-22].

Tunneling allows formation of a super-clot of cytokines and red bone marrow stem cells, which stabilizes through implantation onto the matrix defect and stimulates bone and cartilage-like tissue repairs [23, 24].

AMIC offers a number of distinct advantages: it is minimally invasive; it can remedy larger cartilage defects; it is a simple surgery; its effectiveness has been proved - patients suffer
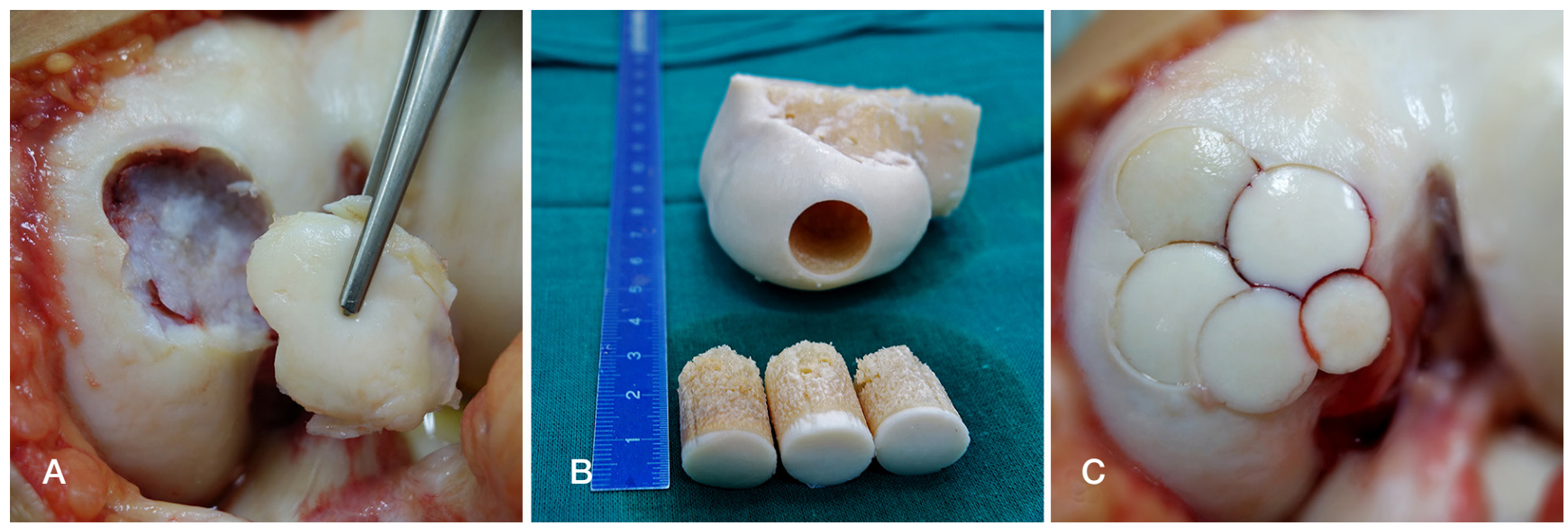

Fig. 3. A. Osteochondral defect of the medial femoral condyle (Koenig's disease). B. Allogeneic lyophilized femoral condyle and cylindrical donor transplants (columns, posts). C. Result of "mosaic" osteochondral allotransplantation
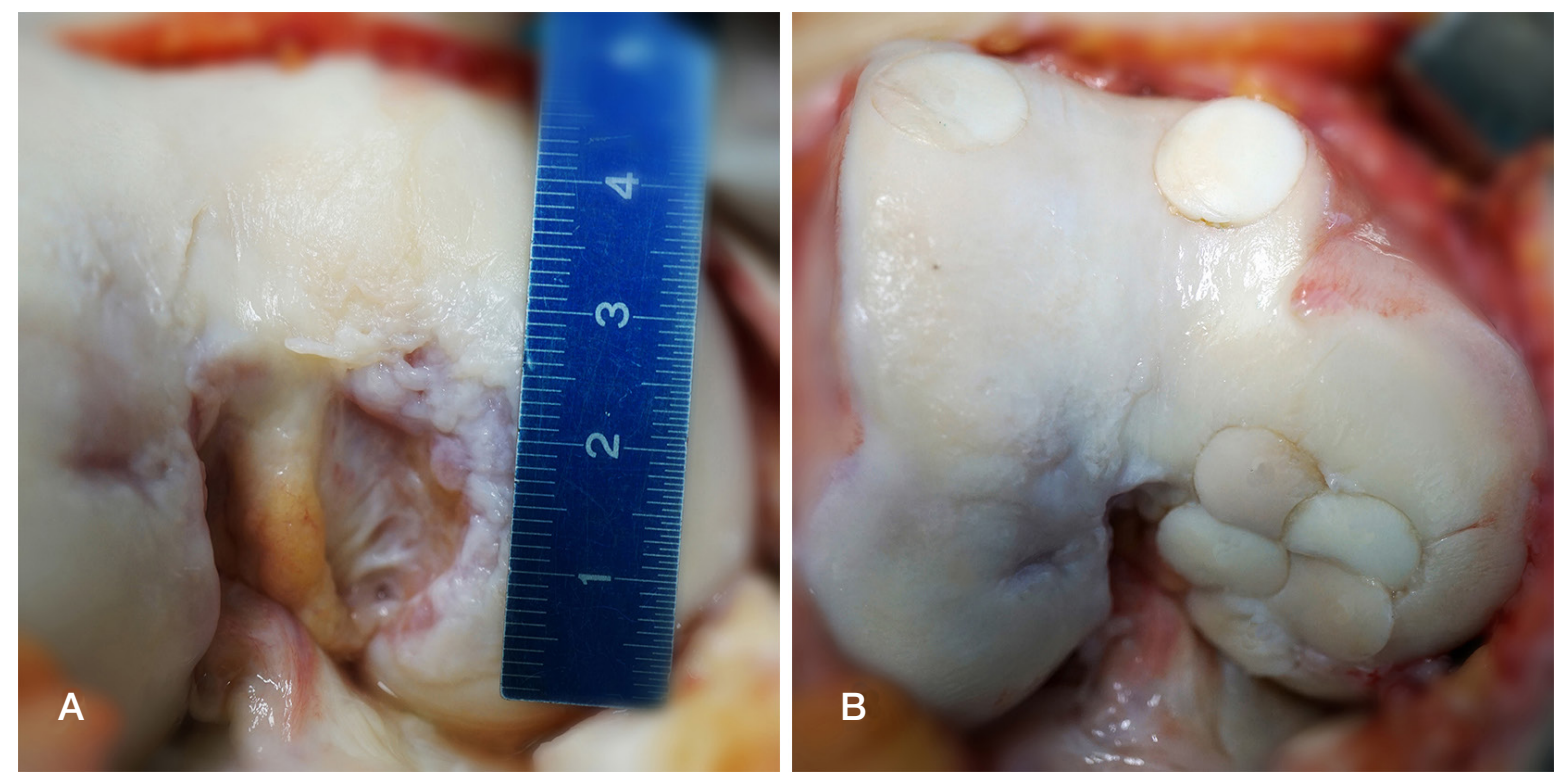

Fig. 4. A. Osteochondral defect of the medial femoral condyle (Koenig's disease), shape and size. B. Result of combined osteochondral autotransplantation. A - auto, E - allo
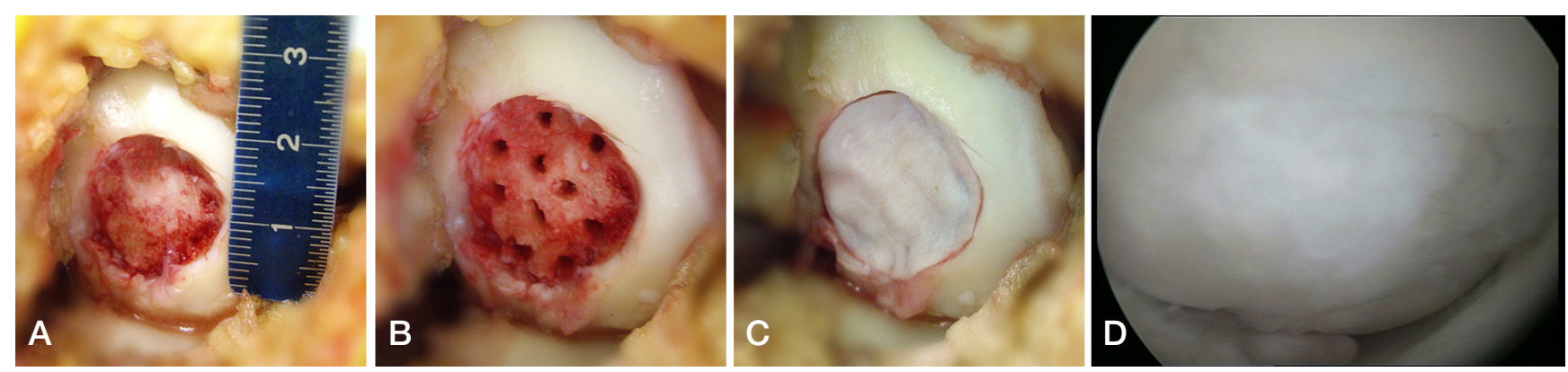

Fig. 5. A. Osteochondral defect of the medial femoral condyle shape and size after sanation. B. Subchondral bone after tunneling. C. Collagen matrix implantation. D. 1.4 years after surgery: condyle defect is completely covered by stable cartilaginous tissue (arthroscopic view) 
lesser pain, in some cases the pain was gone completely and knee functions returned in full, which had positive effect on patient satisfaction.

Today, collagen matrix is the most advanced widely available biological material used to repair cartilage tissue, a material that positively affects stem cell differentiation and chondrogenesis.

We believe this operation is the proper choice for patients with 3rd stage of Koenig's disease (full-thickness defects of hyaline cartilage, no damage to subchondral bone). Prerequisites: healthy hyaline cartilage surrounding the defect, viable subchondral bone and unchanged mechanical axis of the lower limb.

Contraindications: multiple cartilage defects, including "kissing lesions"; widespread knee osteoarthritis; systemic autoimmune diseases; knee joint instability caused by ligament and meniscus injury; valgus or varus leg deformations that call for corrective surgery; allergic reactions to collagen.

Special attention should be paid to the state of the subchondral bone: expressed sclerosis there indicates its nonviability. We believe the non-viable part of the bone should be sanitated up to the healthy, bleeding layers, and the defect remedied through osteoplasty. Lack of pinpoint bleeding after subchondral bone tunneling signals of its non-viability, which should alert the surgeon. In such cases, implantation of a collagen matrix without osteoplasty is fruitless.

The list below presents our recommendations based on the analysis of long-term outcomes of AMIC technique application to our patients.

- A mandatory prerequisite for collagen matrix implantation is healthy and stable subchondral bone.

- Deep (over $5 \mathrm{~mm}$ ) local damage to subchondral bone calls for osteoplasty on the osteochondral defect.

\section{References}

1. Anders S, Wiech O, Schaumburger J, et al. Autologus Matrix induced chondrogenesis (AMIC) for focal chondal defects of the knee - first results. J Bone Joint Surg Br. 2009; 91 (Suppl.1): 83-7.

2. Malanin DA, Pisarev VB, Novochadov V. Vosstanovlenie povregdeniy chryasha $\vee$ kolennom sustave. Eksperimental'nye i klinicheskie aspekty. Volgograd: Volgogradskoe nauchnoe izdatel'stvo; 2010. $455 \mathrm{c}$.

3. Alford JW, Cole BJ. Cartilage restoration, part 1: basic science, historical perspective, patient evaluation and treatment options Am J Sports Med. 2005; 33 (2): 295-306.

4. Solheim E, Hegna J, Inderhaug E, Oyen J, Harlem T, Strand T. Results at 10-14 years after microfracture treatment of articular cartilage defects in the knee. Knee Surg Sports Traumatol Arthroscop. 2016; 24 (5): 1587-93.

5. Xing L, Jiang $Y$, Gui J, Lu $Y$, et al. Microfracture combined with osteochondral paste implantation was more effective than microfracture alone for full-thickness cartilage repair. Knee Surg Sports Traumatol Arthroscop. 2013; 21 (8): 1770-76.

6. Laupattarakasem $\mathrm{W}$, Laopaiboon $\mathrm{M}$, Laupattarakasem $\mathrm{P}_{\text {, }}$ Sumananont C. Arthroscopic debridement for knee osteoarthritis (Review). Cochrane Database Syst Rev. 2008; Issue 1. Art. No.: CD005118. DOI: 10.1002/14651858.CD005118.pub2.

7. Stadnikov AA, Kavalerskiy GM, Arhipov SV, Pavlov VP, Makarov SA, Makarov MA, i dr. Novye metody hirurgicheskogo lecheniya defectov gialinovogo chryasha kolennogo sustava u bol'nyh s gonartrozom. Nauchno-practicheskaya revmatologiya. 2009; 3: 90-3.

8. Tratting S, Ba-Ssalamah A, Pinker K, Plank C, Vescei V, Marlovits S. Magnetic Resonance Imaging. 2005; 23 (7): 779-87.

9. Koval'chul VN. Klassifikaciya povregdeniy chryasha kolennogo
- Simultaneous osteoplasty (on the osteochondral defect, using a biocomposite bone) and matrix implantation is unpromising.

- Physical activity level of the patient should be factored in when planning the surgery. Unfortunately, AMIC and sport of records are incompatible.

\section{CONCLUSION}

Having analyzed the outcomes of treatment done in our hospital, as well as available literature and technical capabilities, we optimized the algorithm for surgical treatment of patients suffering from knee osteochondritis desiccans and arrived at a number of conclusions: 1) patients with open physes should undergo removal of the non-viable cartilaginous plate, sanation of the osteochondral defect and subchondral bone tunneling; 2) AMIC technique is the optimal choice for cases where there is a full-thickness local cartilage damage and undamaged subchondral bone; 3) local osteochondral defects measuring less than $10 \mathrm{~cm}^{2}$ may best be treated with "mosaic" osteochondral autotransplantation; 4) local osteochondral defects measuring $10-15 \mathrm{~cm}^{2}$ call for combined "mosaic" osteochondral transplantation.

In conclusion, we would like to note that through the objective analysis of errors and complications we have managed to change the stereotypes around local cartilage and osteochondral femoral condyle defects treatment tactics, sort out a number of unpromising technologies and improve the surgery procedures. Nevertheless, surgery on knee osteochondritis desiccans is still is subject containing many controversial issues.

sustava. Luchevaya diagnostica, luchevaya terapiya. 2012; 1: 99-106.

10. Golovaha ML, Loskutov AE, Egorov VF. Korrelyacia dannyh magnitno-rezonansnoy tomografii i artroscopii pri travmaticheskih povregdeniyah kolennogo sustava. Praktikyushemu vrachu. 2011; 12 (2): 99-105.

11. Lazishvili GD, Zatikyan VR, Shukyur-Zadeh ER, Kornaev AS, Akmataliev KI, Danilov MA. Actual direction of chondroplasty. Bulletin of Russian State Medical University. 2013; 3: 13-17.

12. Malyshev EE, Korolyov SB, Pavlov DV, Kuvshinov SG. Osteochondral autoplasty of the extensive post-traumatic defect of the proximal tibia. Modern technologies in medicine. 2014; 6 (2): 142-7.

13. Kotel'nikov GP, Larcev YV, Kudashev DS, Zuev-Ratnikov SD, Shorin IS. Mosaicplasty in the treatment of patients with destructive-dystrophic and post-traumatic lesions hyaline cartilage in the knee joint - experimental and clinical aspects. Fundamental research. 2013; 9: 252-5.

14. Zakirova AR. Artroskopicheskoe lechenie hrjashevyh defectov kolennogo sustava. M.: 2010.

15. Caldwell PE, Shelton WR. Indications for allografts. Orthop Clin North Am. 2005; 36 (4): 459-67.

16. Sadlik B, Wiewiorski M. Implantation of a collagen matrix for an AMIC repair during dry arthroscopy. Knee Surg Sports Traumatol Arthrosc. 2015; 23: 2349-52.

17. Gille J, Schuseil E, Wimmer J, et al. Mid-term results of autologus matrix-indused chondrogenesis for treatment of focal cartilage defects in the knee. Knee Surg Sports Traumatol Arthrosc. 2010; 18: 1456. https://doi.org/10.1007/s00167-010-1042-3.

18. Pascarella A, Ciatti R, Pascarella F, et al. Treatment of articular cartilage lesions of the knee joint using a modified AMIC technique. 
Knee Surg Sports Traumatol. Arthrosc. 2010; 18: 509-13.

19. Anders S, Wiech O, Schaumburger J, et al. Autologus Matrix induced chondrogenesis (AMIC) for focal chondal defects of the knee - first results. J Bone Jt Surg (Brit.). 2009; 91 (suppl.1): 834.

20. Hangody L, Vasarhelyi G, Hangody LR, et al. Autologus osteochondral grafting technique and long-term results. Injury. 2008; 39 (suppl.1): 32-9.

21. Steinwachs M, Kreuz PC. Autologus chondrocyte implantation in chondral defects of the knee with a type I/III collagen membrane: A prospective study with a 3-year follow-up. Arthroscopy. 2007; 23: $381-7$.

\section{Литература}

1. Anders $\mathrm{S}$, Wiech $\mathrm{O}$, Schaumburger J, et al. Autologus Matrix induced chondrogenesis (AMIC) for focal chondal defects of the knee - first results. J Bone Joint Surg Br. 2009; 91 (Suppl.1): 83-7.

2. Маланин Д. А., Писарев В. Б., Новочадов В. В. Восстановление повреждений хряща в коленном суставе. Экспериментальные и клинические аспекты. Волгоград: Волгоградское научное издательство; 2010. 455 с.

3. Alford JW, Cole BJ. Cartilage restoration, part 1: basic science, historical perspective, patient evaluation and treatment options. Am J Sports Med. 2005; 33 (2): 295-306.

4. Solheim E, Hegna J, Inderhaug E, Oyen J, Harlem T, Strand T. Results at 10-14 years after microfracture treatment of articular cartilage defects in the knee. Knee Surg Sports Traumatol Arthroscop. 2016; 24 (5): 1587-93.

5. Xing L, Jiang $Y$, Gui J, Lu Y, et al. Microfracture combined with osteochondral paste implantation was more effective than microfracture alone for full-thickness cartilage repair. Knee Surg Sports Traumatol Arthroscop. 2013; 21 (8): 1770-76.

6. Laupattarakasem $\mathrm{W}$, Laopaiboon $\mathrm{M}$, Laupattarakasem $\mathrm{P}$, Sumananont C. Arthroscopic debridement for knee osteoarthritis (Review). Cochrane Database Syst Rev. 2008; Issue 1. Art. No.: CD005118. DOI: 10.1002/14651858.CD005118.pub2.

7. Стадников А. А., Кавалерский Г. М., Архипов С. В., Павлов В. П., Макаров С. А., Макаров М.А. и др. Новые методы хирургического лечения дефектов гиалинового хряща коленного сустава у больных с гонартрозом. Научно практическая ревматология. 2009; 3: 90-3.

8. Tratting S, Ba-Ssalamah A, Pinker K, Plank C, Vescei V, Marlovits S. Magnetic Resonance Imaging. 2005; 23 (7): 779-87.

9. Ковальчук В. Н. Классификация поврежденного хряща коленного сустава. Лучевая диагностика, лучевая терапия. 2012; 1: 99-106.

10. Головаха М. Л., Лоскутов А. Е., Егоров В.Ф. Корреляция данных магнитно- резонансной томограсии и артроскопии при травматических повреждениях коленного сустава Практикующему врачу. 2011; 12 (2): 99-105.

11. Лазишвили Г.Д., Затикян В. Р., Шукюр-Заде Э. Р., Корнаев А. С., Акматалиев К. И., Данилов М. А. Актуальные вопросы хондропластики. Вестник РГМУ. 2013; 3: 13-17.

12. Малышев Е. Е., Королев С. Б., Павлов Д. В., Кувшинов С. Г. Костно-хрящевая аутотранплантация обширного посттравматического десекта проксимального отдела большеберцовой кости. Современные технологии в
22. Garkavi AV, Blokov MY. Artroscopicheskaya chondroplastika lokal'nych chryashevyh defectov kolennogo sustava s ispol'zovaniem kollagenovoy membrany CHONDRO-GIDE. Kafedra travmatologii i ortopedii. 2015; 3 (15): 4-7.

23. Jacob RP. AMIC technique for cartilage repair, a single-step surgical intervention as compared to other methods. Eur Cell Mater. 2006; 12 (suppl.1): 26-32.

24. Kramer J, Bohrnsen F, Lindner $U$, et al. In vivo matrix-guided human mesenchymal stem cells. Cell Mol Life Sci. 2006; 63 (5): 616-26.

медицине. 2014; 6 (2): 142-7.

13. Котельников Г. П., Ларцев Ю. В., Кудашев Д. С., ЗуевРатников С. Д., Шорин И. С. Мозаичная хондропластика в лечении больных с деструктивно-дистрофическими и посттравматическими поражениями гиалинового хряща в коленном суставе - экспериментальные и клинические аспекты. Фундаментальные исследования. Медицинские науки. 2013; 9: 252-5.

14. Закирова А. Р. Артроскопическое лечение хрящевых десектов коленного сустава. М.: 2010.

15. Caldwell PE, Shelton WR. Indications for allografts. Orthop Clin North Am. 2005; 36 (4): 459-67.

16. Sadlik B, Wiewiorski M. Implantation of a collagen matrix for an AMIC repair during dry arthroscopy. Knee Surg Sports Traumatol Arthrosc. 2015; 23: 2349-52.

17. Gille J, Schuseil E, Wimmer J, et al. Mid-term results of autologus matrix-indused chondrogenesis for treatment of focal cartilage defects in the knee. Knee Surg Sports Traumatol Arthrosc. 2010; 18: 1456. https://doi.org/10.1007/s00167-010-1042-3.

18. Pascarella A, Ciatti R, Pascarella F, et al. Treatment of articular cartilage lesions of the knee joint using a modified AMIC technique. Knee Surg Sports Traumatol. Arthrosc. 2010; 18: 509-13.

19. Anders S, Wiech O, Schaumburger J, et al. Autologus Matrix induced chondrogenesis (AMIC) for focal chondal defects of the knee - first results. J Bone Jt Surg (Brit.). 2009; 91 (suppl.1): 834.

20. Hangody L, Vasarhelyi G, Hangody LR, et al. Autologus osteochondral grafting technique and long-term results. Injury. 2008; 39 (suppl.1): 32-9.

21. Steinwachs M, Kreuz PC. Autologus chondrocyte implantation in chondral defects of the knee with a type I/III collagen membrane: A prospective study with a 3-year follow-up. Arthroscopy. 2007; 23: 381-7.

22. Гаркави А. В., Блоков М. Ю. Артроскопическая хондропластика локальных хрящевых десектов коленного сустава с использованием коллагеновой мембраны CHONDRO-GIDE. Касредра травматологии и ортопедии. 2015; 3 (15): 4-7.

23. Jacob RP. AMIC technique for cartilage repair, a single-step surgical intervention as compared to other methods. Eur Cell Mater. 2006; 12 (suppl.1): 26-32.

24. Kramer J, Bohrnsen F, Lindner U, et al. In vivo matrix-guided human mesenchymal stem cells. Cell Mol Life Sci. 2006; 63 (5): 616-26. 